
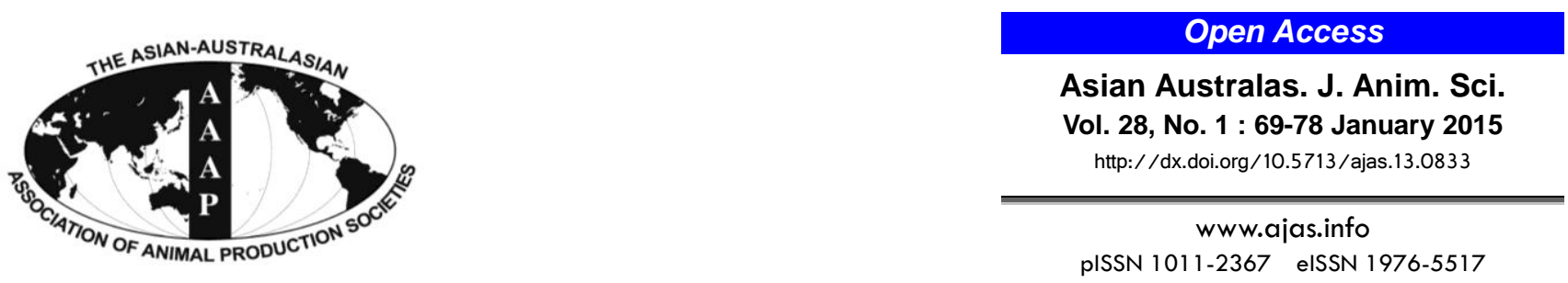

\title{
Effect of Heifer Frame Score on Growth, Fertility, and Economics
}

\author{
S. Şentürklï ${ }^{1,2, *}$, D. G. Landblom ${ }^{1}$, G. A. Perry ${ }^{3}$, and T. Petry ${ }^{4}$ \\ ${ }^{1}$ Dickinson Research Extension Center, North Dakota State University, \\ Dickinson, ND 58601, USA
}

\begin{abstract}
A non-traditional forage-based protocol was employed to evaluate replacement heifer growth, fertility, and economics between small frame $(\mathrm{SF}, 3.50 ; \mathrm{n}=50)$ and large frame $(\mathrm{LF}, 5.56 ; \mathrm{n}=50)$ heifers using three increasing gain growth phases. Preceding an 85 d growing-breeding period (Phase 3; P3) the heifers were managed as a common group for Phases 1 and 2 (P1 and P2). During P1, heifers grazed common fields of unharvested corn and corn residue (total digestible nutrients [TDN] 56\%) with supplemental hay. For P2, heifers grazed early spring crested wheatgrass pasture (CWG; TDN 62\%) that was followed by the final P3 drylot growing and breeding period (TDN 68\%). Small frame heifers were lighter at the end of P1 in May and at the start of P3 breeding in August ( $\mathrm{p}=$ 0.0002). Percent of mature body weight (BW) at the end of P1 (209 d) was $48.7 \%$ and $46.8 \%$, respectively, for the SF and LF heifers and the percent pubertal was lower for SF than for LF heifers $(18.0 \%$ vs $40.0 \%$; $=0.02)$. At breeding initiation $(\mathrm{P} 3)$, the percentage of mature BW was 57.8 and 57.2 and the percentage pubertal was 90.0 and $96.0(\mathrm{p}=0.07)$ for the SF and LF heifers, respectively; a 5-fold increase for SF heifers. Breeding cycle pregnancy on days 21, 42, and 63, and total percent pregnant did not differ ( $p>0.10$ ). In drylot, SF heifer dry matter intake (DMI) was $20.1 \%$ less $(p=0.001)$ and feed cost $/ \mathrm{d}$ was $20.3 \%$ lower $(\mathrm{p}=0.001)$, but feed cost $/ \mathrm{kg}$ of gain did not differ between SF and LF heifers $(\mathrm{p}=0.41)$. Economically important live animal measurements for muscling were measured in May and at the end of the study in October. SF heifers had greater $L$. dorsi muscle area per unit of BW than LF heifers $(p=0.03)$. Small frame heifer value was lower at weaning $(p=0.005)$ and the non-pregnant ending heifer value was lower for SF heifers than for the LF heifers $(p=0.005)$. However, the total development cost was lower for SF heifers $(p=0.001)$ and the net cost per pregnant heifer, after accounting for the sale of non-pregnant heifers, was lower for SF heifers $(p=0.004)$. These data suggest that high breeding efficiency can be attained among March-April born SF and LF virgin heifers when transitioned to a more favorable May-June calving period through the strategic use of grazed and harvested forages resulting in a lower net cost per pregnant SF heifer. (Key Words: Beef Heifer, Heifer Production Economics, Fertility, Frame Score, Increasing Energy Management, Percent Mature Body Weight)
\end{abstract}

\section{INTRODUCTION}

Livestock enterprise analysis for beef replacement heifers has identified feed as the largest single expense for raising replacement heifers, which is estimated to range from $72 \%$ to $86 \%$ of total direct expenses for a heifer ready

\footnotetext{
* Corresponding Author: S. Şentürklü. Tel: +90-286-3162878, Fax: +90-286-3163733, E-mail: ssenturklu@ comu.edu.tr

${ }^{2}$ Department of Animal Science, Çanakkale Onsekiz Mart Univ. Çanakkale 17200, Turkey.

${ }^{3}$ Department of Animal Sciences, South Dakota State University, Brookings, SD 57007, USA.

${ }^{4}$ Department of Agribusiness and Applied Economics, North Dakota State University, Fargo, ND 58105, USA.

Submitted Dec. 19, 2013; Revised Mar. 24, 2014; Accepted Jul. 10, 2014
}

to calve (ND Farm Business Management Education Program 2010,2011,2012; Dhuyvetter et al., 2012). Therefore, the cow-calf segment of the United States beef cattle industry is moving toward a more moderate cow size and less intense production practices in an effort to reduce nutritional needs, increase pasture stocking rates, and subsequently, reduce development cost.

Traditional development procedures recommend that heifers be grown to attain $60 \%$ to $65 \%$ of mature BW by the start of the breeding season using high energy inputs based on the supposition that high pregnancy rates are dependent on early puberty onset (Short and Bellows, 1971; Lesmeister et al., 1973) and that 2-3 estrous cycles before the initiation of breeding are necessary for maximum reproductive efficiency (Byerley et al., 1987; Perry et al., 
1991). Freelty et al. (2011) reported, for Bos taurus, that the proportion of mature BW at puberty was $56 \%$ to $58 \%$, and attainment of this proportion of mature BW was a better predictor of age at puberty than absolute weight or age. Compared to the constant rate of gain method for heifer development, using a stair-step, alternating gain, procedure has been shown to improve conception and pregnancy rates (Fox et al., 1988; Patterson et al., 1992; Lynch et al., 1996; Grings et al., 1999; Poland and Ringwall, 2001). More recently, less intense development protocols have reduced the breeding target weight goal to $50 \%$ to $57 \%$ of mature cow BW by relying on lower-cost, lower-energy, systems and compensatory gain (Funston and Deutscher, 2004; Roberts et al., 2009; Funston and Larson, 2011; Larson et al., 2011; Endecott et al., 2013).

Using a frame scoring system, as described by the Beef Improvement Federation (BIF), cattlemen can evaluate complex systems using a simple hip height measurement converted to a linear measurement to estimate an animal's potential lean-to-fat ratio (1 to 9 scoring system for bulls and heifers) (BIF, 2010). In general, small frame (SF) animals ( $\leq 4.5$ frame score) are smaller stature, easier fleshing, and attain physiological maturity earlier in life, compared to large frame (LF) animals ( $\geq 4.5$ frame score) that tend to be heavier regardless of life stage, leaner, and reach physiological maturity later in life (BIF, 2010). Using the uniform frame scoring system, cattlemen can identify mature cattle frame sizes that best fit a given environment and feed resource.

After weaning, and prior to an increasing dietary energy regimen, SF and LF heifers grazed dormant unharvested corn with supplemental hay followed by early spring grazing of crested wheatgrass (CWG) pasture. The objective of this heifer development study was to compare heifer growth, reproductive performance, and development cost of SF and LF heifers subjected to a protocol of increasing dietary energy. We hypothesized that SF and LF heifer reproductive performance would be similar, but that SF heifer production cost would be lower throughout the entire development period and the cost per pregnant SF heifer would be less.

\section{MATERIALS AND METHODS}

This grazing and drylot forage-based heifer development and breeding study was conducted at the North Dakota State University, Dickinson Research Extension Center (DREC) $\left(47^{\circ} 11^{\prime} 40^{\prime \prime} \mathrm{N} 102^{\circ} 50^{\prime} 23^{\prime \prime} \mathrm{W}\right)$ located $35 \mathrm{~km}$ north of Dickinson, ND, USA, in accordance with guidelines approved by the North Dakota State University Institutional Animal Care and Use Committee (Approval Number A12007).

One hundred beef heifer calves originating from two separate frame size cow herds at the DREC were weaned mid-October 2010 and weaning weight and hip height measurements were recorded. Using heifer age and hip height measurement, frame score values were determined for each heifer according to the BIF procedure for 5 to 21 month old heifers (BIF, 2010). Based on computed heifer frame score values, the heifers were assigned to either the SF (Range: 2.4 to 4.2 ; mean: $3.50 \pm 0.697$ ) or LF (Range: 4.6 to 6.5 ; mean: $5.56 \pm 0.569$ ) treatment groups. Genetic composition of the SF heifers was obtained through mating of conventional LF crossbred cows (Angus $\times$ Red Angus $\times$ Gelbvieh or Angus $\times$ Red Angus $\times$ Simmental) with Lowline sires resulting in SF heifers that were one-half Lowline.

\section{Pre-trial increasing gain management}

Phase 1 (P1), the baseline for an increasing energy regimen started on October 13, 2013, when 7.5 month old SF and LF heifers began grazing 14.7 ha of standing unharvested corn together as a common group (Table 1). Corn was planted using a John Deere 6-row planter set at $0.762 \mathrm{~m}$ row spacing for a plant population of 7,692 plants per ha. Corn forage dry matter (DM) yield was $4.91 \mathrm{mt} / \mathrm{ha}$ and the crude protein (CP) content at the start of grazing was $9.72 \%$ and neutral detergent fiber (NDF) content was 51.1\% (Detail: Forage and Supplement Analysis Section). As the heifers grazed standing corn with unrestricted access, forage quality declined with the advancing winter season (December 4, 2010; 7.75\% CP and 70.2\% NDF). Beginning December 4 , the corn residue was supplemented with a medium-quality mixed hay (smooth bromegrass, Bromus inermis; CWG, Agropryon desertorum; alfalfa, Medicago sativa) (Table 1) until May 10, 2011; a period of 209 d. Hay was delivered to the heifers in large round bales $(1.67 \times 1.52$ m) and fed in cone-type round bale feeders (Weldy Enterprises, 911 E. Waterford St., Wakaruse, IN 46573, USA). Since the SF and LF heifers were managed as a common group, heifer dry matter intake (DMI) for corn and hay was estimated based on the average DMI for all heifers (corn forage $5.79 \mathrm{~kg} / \mathrm{d}$, hay $5.21 \mathrm{~kg} / \mathrm{d}$ ) and then adjusted to account for SF and LF heifer intake difference. The adjustment for estimated DMI was calculated according to the following formula: $2 \mathrm{y}=(1.0+0.799) \mathrm{x}$, where $\mathrm{y}$ is average DMI for corn or hay and $\mathrm{x}$ is DMI for the LF heifer. Thus, the SF heifer DMI is solved by subtraction. The estimated corn forage and hay DMI for SF heifers were 5.14 and $4.63 \mathrm{~kg} / \mathrm{d}$, and LF heifers were 6.44 and $5.79 \mathrm{~kg} / \mathrm{d}$, respectively. At the end of the P1 wintering period, heifer BW, ultrasound Longissimus dorsi muscle area (LMA), LMA/unit of BW $\left(\mathrm{cm}^{2}\right), 12$ th rib fat thickness and percent intramuscular fat (IMF) were recorded, and blood was drawn for progesterone assay. This pre-trial wintering procedure restricted average daily gain (ADG) for the SF and LF heifers creating a basis for increased growth rate 
Table 1. Forage, hay, TMR, and co-product supplement nutrient analysis, and co-product supplement composition (DM)

\begin{tabular}{|c|c|c|c|c|c|c|c|c|c|c|}
\hline & \multicolumn{6}{|c|}{ Forage and hay } & \multicolumn{4}{|c|}{ Co-product supplement } \\
\hline & $\begin{array}{l}\text { Unharvested } \\
\text { corn }^{1}\end{array}$ & $\begin{array}{l}\text { Corn } \\
\text { residue }^{1}\end{array}$ & $\begin{array}{l}\text { Mixed } \\
\text { Hay }^{1}\end{array}$ & $\begin{array}{l}\text { Spring } \\
\mathrm{CWG}^{2}\end{array}$ & $\begin{array}{l}\text { Alfalfa } \\
\text { hay }^{3}\end{array}$ & $\begin{array}{l}\text { Feedlot } \\
\text { TMR }^{4}\end{array}$ & Composition $^{5}$ & & Analysis ${ }^{6,7}$ & \\
\hline$\overline{\mathrm{CP}}(\%)$ & 9.72 & 7.75 & 11.3 & 11.3 & 18.4 & 18.9 & DDGS (\%) & 30.23 & $\mathrm{CP}(\%)$ & 20.39 \\
\hline $\operatorname{ADF}(\%)$ & 29.3 & 41.8 & 37.3 & 34.4 & 32.0 & 28.6 & BMS (\%) & 30.00 & $\operatorname{ADF}(\%)$ & 13.88 \\
\hline $\operatorname{NDF}(\%)$ & 51.1 & 70.2 & 56.7 & 63.6 & 43.3 & 42.5 & $\mathrm{WM}(\%)$ & 15.00 & $\operatorname{NDF}(\%)$ & 36.65 \\
\hline TDN (\%) & 67.4 & 56.3 & 62.1 & 59.0 & 63.4 & 67.8 & $\mathrm{SH}(\%)$ & 7.75 & Crude fat $(\%)$ & 13.14 \\
\hline IVDMD (\%) & 74.1 & 50.0 & 67.1 & 68.1 & 72.1 & 77.1 & Fat $(\%)$ & 7.5 & Fiber $(\%)$ & 11.85 \\
\hline IVOMD (\%) & 72.5 & 46.6 & 66.9 & 67.9 & 69.7 & 74.5 & Molasses (\%) & 5.00 & $\operatorname{Starch}(\%)$ & 5.99 \\
\hline Calcium (\%) & 0.21 & 0.21 & 1.22 & 0.39 & 1.55 & 1.29 & Sodium phos $(\%)$ & 3.25 & Calcium (\%) & 0.19 \\
\hline Phosphorus (\%) & 0.33 & 0.09 & 0.16 & 0.24 & 0.19 & 0.43 & Salt $(\%)$ & 0.75 & Phosphorus (\%) & 1.56 \\
\hline NEm (Mcal/kg) & 1.67 & 1.30 & 1.41 & 1.42 & 1.55 & 1.65 & Urea (\%) & 0.35 & $\mathrm{NEm}(\mathrm{Mcal} / \mathrm{kg})$ & 2.07 \\
\hline NEg (Mcal/kg) & 0.95 & 0.64 & 0.69 & 0.70 & 0.83 & 0.95 & TM pre-mix (\%) & 0.15 & NEg (Mcal/kg) & 1.41 \\
\hline ME (Mcal/kg) & 2.51 & 2.29 & 2.20 & 2.22 & 2.37 & 2.51 & Vit. pre-mix $(\%)$ & 0.025 & $\mathrm{ME}(\mathrm{Mcal} / \mathrm{kg})$ & 3.07 \\
\hline
\end{tabular}

TMR, total mixed ration; DM, dry matter; CWG, crested wheatgrass; CP, crude protein; DDGS, distiller's dried grain with solubles; ADF, acid detergent fiber; BMS, barley malt sprouts; NDF, neutral detergent fiber; WM, wheat middlings; TDN, total digestible nutrients; SH, soybean hulls; IVDMD, in vitro dry matter disappearance; IVOMD, and in vitro organic matter disappearance; NEm, net energy maintenance; NEg, net energy gain; ME, metabolizable energy.

${ }^{1}$ Unharvested corn, corn residue, and supplemental hay fed during the $209 \mathrm{~d}$ period between October and May 2011.

${ }^{2} \mathrm{CWG}$ grazed during the early spring and summer prior to feedlot confinement for growing and breeding.

${ }^{3}$ Alfalfa hay fed during the $85 \mathrm{~d}$ feedlot confinement growing and breeding period.

${ }^{4}$ TMR, $80 \%$ alfalfa and $20 \%$ co-product supplement.

${ }^{5}$ Composition of co-product supplement fed with alfalfa hay during the feedlot confinement growing and breeding period.

${ }^{6}$ Trace mineral content: potassium, $0.77 \%$; sodium, $1.33 \% \%$ chloride, $0.64 \%$; magnesium, $0.19 \%$; sulfur, $0.41 \%$; manganese, 169.13 ppm; iron, 103.22 ppm; copper, 106.01 ppm; zinc, 377.64 ppm; cobalt, 1.81 ppm; iodine, 8.86 ppm.

${ }^{7}$ Vitamin content: vitamin E, $22.12 \mathrm{IU}$; vitamin A, $22.12 \mathrm{IU}$; vitamin $\mathrm{D}_{3} 2.21 \mathrm{IU}$; thiamine, $1.98 \mathrm{mg}$.

during phase $2(\mathrm{P} 2)$ and phase $3(\mathrm{P} 3)$.

Phase 2 began on May 10, 2011, when the heifers began grazing a common CWG pasture, and continued until July 6 , 2011 (58 d). The stocking density while grazing CWG was based on 0.40469 ha per animal unit month (AUM), or SF = 0.253 and $\mathrm{LF}=0.294$ ha per heifer per month, which was based on an estimated heifer mid-weight between May 10 and July 6 of 284 and $330 \mathrm{~kg}$ for the SF and LF heifers, respectively. During the CWG grazing period, the SF and LF heifers were predicted to utilize 0.49 and 0.57 ha per heifer, respectively.

\section{Experimental design}

When the heifers were removed from the CWG pasture on July 6, 2011, they were weighed and assigned to drylot pens $(19.5 \mathrm{~m} \times 31.7 \mathrm{~m})$ for the replicated $\mathrm{P} 3$ growing and breeding study. Heifers within each frame score treatment group (SF, $\mathrm{n}=50 ; \mathrm{LF}, \mathrm{n}=50$ ) were allotted according to weight within 5 weight block pens with 10 heifers per pen. Thus, there were 5 pen weight blocks of SF heifers and 5 pen weight blocks of LF heifers. Drylot pen group served as the experimental unit for the study that started on July 6, 2011 and ended on September 29, 2011.

\section{Diets}

Without feeding grain to increase energy during the P3 growing-breeding period, a total mixed ration (TMR) consisting of $80 \%$ alfalfa and a $20 \%$ co-product supplement was fed (Table 1). Attainment of approximately $57 \%$ of mature $\mathrm{BW}$ at the start of the breeding season was an essential benchmark in this non-traditional forage-based heifer development investigation (Freetly et al., 2011). Therefore, heifer growth rate between CWG and the start of the breeding season in drylot was crucial and feeding alfalfa alone would not provide sufficient dietary energy to meet the $57 \%$ of mature BW goal, because alfalfa as the sole ingredient would only supply sufficient energy to support ADG of approximately $0.30 \mathrm{~kg} / \mathrm{d}$; or one-third of the projected 0.85 to $0.95 \mathrm{~kg} / \mathrm{d}$ needed to meet the target goal at the start of the breeding season. The resulting TMR (80\% alfalfa $+20 \%$ co-product supplement) was fed ad libitum in fence line concrete bunks and provided $2.51 \mathrm{Mcal}$ of metabolizable energy (ME)/kg of diet (Table 1). On a daily basis, the diet was estimated to provide 23.7 and $28.5 \mathrm{Mcal}$ ME/d for the SF and LF heifers, respectively. Prior to TMR mixing, the alfalfa hay had been previously chopped by a local commercial hay grinding company using a $7.62 \mathrm{~cm}$ screen. The TMR ration was delivered to the bunks daily using a Gehl feedlot mixing wagon (Model 8400, Farmers Implement, LLC, Allenton, WI, USA) equipped with DigiStar EZ 2000 electronic scale (Digi-Star, LLC, Fort Atkinson, WI, USA).

\section{Forage and supplement analysis}

Prior to diet formulation, $40 \%$ of the alfalfa bales fed in the study were core sampled using a $1.27 \mathrm{~cm}$ electric drill 
and a stainless steel Penn State Forage Sampler $(2.9 \mathrm{~cm} \times$ $45.7 \mathrm{~cm}$, Nasco Agricultural Sciences, Fort Atkinson, WI, USA) and analyzed by a commercial laboratory for $\mathrm{CP}$, NDF, acid detergent fiber (ADF), calcium $\left(\mathrm{Ca}^{++}\right)$, phosphorus (P), total digestible nutrients (96.35(ADF\% $\times 1.15)$, in vitro dry matter disappearance (IVDMD), and in vitro organic matter disappearance (IVOMD), (Table 1; AgSource Soil and Forage Laboratory, Bonduel, WI, USA).

The co-product supplement (Table 1) that was mixed with alfalfa for the TMR diet fed in drylot was prepared commercially as a $0.635 \mathrm{~cm}$ pellet and supplement nutrient analysis and energy density were provided by the company (Cenex Harvest States Nutrition, Sioux Falls, South Dakota, USA).

Pre-grazing corn forage yield and nutrient analysis and corn residue nutrient analysis were determined from 5 equidistant sampling sites along a diagonal field transect. At each sampling site, $5.03 \mathrm{~m}$ of corn was removed with a machete, bundled, weighed, and shredded with a forage shredder (Snapper LEAF Shredder-Chipper Model LS5000, Briggs \& Stratton, Attn: Snapper Power Products, Milwaukee, WI, USA). The wet shredded forage from each sampling site was weighed before placement in a forage drying oven for 72 hours at $135^{\circ} \mathrm{C}$. After drying, the samples were weighed and the percent DM and DM yield per ha were determined. The dried samples were mixed and subsampled for nutrient analysis.

The CWG pasture was sampled at the start, mid-point, and at the end of the $58 \mathrm{~d}$ grazing period using a $0.25 \mathrm{~m}$ frame. Forage biomass was clipped to ground level and stored in pre-weighed paper bags. Forage bags were weighed and dried as previously described and composited for nutrient analysis. Grazed forages (corn, corn residue, and $\mathrm{CWG}$ ) and feedlot TMR were analyzed for CP, NDF, ADF, IVDMD, IVOMD, $\mathrm{Ca}$, and $\mathrm{P}$ at the North Dakota State University Nutrition Laboratory (Table 1). Samples were analyzed in duplicate according to the Association of Official Analytical Chemists, AOAC (2010) for DM by drying at $135^{\circ} \mathrm{C}$ (AOAC method 930.15), CP (AOAC method, 2001.11), and $\mathrm{Ca}$ and $\mathrm{P}$ (AOAC methods 968.08 and 965.17). Laboratory analysis for NDF and ADF were based on the procedure of Goering and Van Soest (1970), IVDMD and IVOMD analysis was based on the procedure of Tilley and Terry (1963).

\section{Data collection and assay}

The amount of TMR ration delivered to each pen was recorded daily and orts were removed, weighed, and deducted from each pen's feed record bi-monthly. As fed feed weight was recorded for each pen and pen DMI was calculated based on percent moisture content of the alfalfa hay and co-product supplement ingredients.
Heifer BW (2-day mean; no feed or water restriction) was recorded at weaning and then at each forage phase change, drylot entry, start of the breeding season on August 11, 2011, and at the end of the drylot breeding period. Mature cow BW was used to calculate the heifer percent of mature BW at the start of the breeding season on August 11, 2011 and was based on historical mature cow BW taken from the DREC cow herd database (Herd Number-38) for each frame score group (CHAPS, 2000; Individual producer CHAPS, 2000 herd values are confidential and not open to public access). The estimated mature cow BW used for calculation of heifer percent mature BW was $554 \mathrm{~kg}$ for the SF heifers and $667 \mathrm{~kg}$ for the LF heifers.

The number of heifers cycling at the end of the wintering period and at the start of the $50 \mathrm{~d}$ breeding season on August 11, 2011 was based on the circulating progesterone assay derived from serum recovered from two blood draws collected $10 \mathrm{~d}$ apart. Circulating concentrations of progesterone were analyzed in all serum samples using the methodology described by Engel et al. (2008). Intra and interassay coefficient of variation for progesterone assays were $2.47 \%$ and $5.9 \%$, respectively. A progesterone concentration greater than $1 \mathrm{ng} / \mathrm{mL}$ in either sample was interpreted to indicate presence of a functional corpus luteum and attainment of puberty.

Heifers in the study were bred naturally using fertility tested yearling bulls. The yearling bulls were placed with the heifers on August 11, 2011, for May to June 2012 calving, and remained with the heifers until the end of a 50 d breeding period that ended on September 29, 2011. Breeding cycle pregnancy rate (first cycle, $21 \mathrm{~d}$; second cycle, $42 \mathrm{~d}$; third cycle, $63 \mathrm{~d}$ ), overall pregnancy rate, and the percent of non-pregnant heifers were determined using transrectal ultrasound cranial width measurements (eye socket to eye socket external edge) taken $30 \mathrm{~d}$ after the end of a $50 \mathrm{~d}$ breeding season.

Non-invasive real-time ultrasound was used to estimate changes in economically important live animal carcass traits that relate to muscling and meat quality, which are important criterion for replacement heifer selection included LMA, LMA/unit of BW $\left(\mathrm{cm}^{2}\right)$, 12th rib fat thickness, and percent IMF, and were obtained using an Aloka 500 realtime ultrasound machine equipped with a $17 \mathrm{~cm}$ probe, gel standoff, PXC200 frame grabber, and UISC-USB-2820 Capture Technology (The National CUP Lab \& Technology Center, Ames, IA, USA).

\section{Economics}

Replacement heifer production economics were computed upon completion of the study and were based on the direct expenses associated with each of the increasing energy phases. Actual crop production costs were used for the unharvested corn that was grazed and the mixed hay and 
alfalfa were priced at local opportunity cost. Corn production cost was $\$ 376.16 /$ ha, or $\$ 53.23 /$ heifer. The mixed hay that was fed was priced at $\$ 55.15 / \mathrm{mt}$, or $\$ 70.65 /$ heifer. The average total P1 corn forage and hay feed cost per heifer was $\$ 123.88$. However, feed intake differences recorded during the feedlot $\mathrm{P} 3$ revealed that the SF heifers consumed $20.1 \%$ less DM feed than the LF heifers $(p=0.001)$. For the economic analysis after the animal performance and reproduction data collections were completed, we assumed that the difference in feed consumption would have been similar during the pre-trial grazing phases and; therefore, was used to adjust the proportion of the total feed cost assigned to the SF and LF heifer groups in $\mathrm{P} 1$ and $\mathrm{P} 2$. Thus, for $\mathrm{P} 1$, the proportion of the feed cost credited to the LF heifers was determined according to the following formula: $2 \mathrm{y}=(1.0+0.799) \mathrm{x}$, where $\mathrm{y}$ is the feed cost for the average heifer, and $\mathrm{x}$ is the feed cost for the LF heifer. Feed cost for the LF heifer was computed to be $\$ 137.72 /$ heifer, and by subtraction ( $\$ 247.76$ -\$137.72) the SF heifer portion of the total feed cost was determined to be $\$ 110.04$.

Stocking density for heifers grazing $\mathrm{CWG}$ has been previously described and was based on an estimated midweight heifer BW projection for the grazing period between May 10, 2011 and July 6, 2011 (58 d). Grazing charge for CWG was priced at $\$ 37.07 /$ ha (USDA, NASS, 2011) and the heifers grazed for 1.93 AUM. The SF and LF heifers were calculated to have grazed 0.489 and 0.578 ha, respectively, resulting in a pasture charge of $\$ 18.12$ for the SF heifers and \$21.42 for the LF heifers.

Alfalfa hay was priced into the analysis at $\$ 66.18 / \mathrm{mt}$ and the pelleted $20 \%$ co-product supplement was manufactured commercially (Harvest States Nutrition, Dickinson, ND, USA) and was priced into the analysis at $\$ 420.24 / \mathrm{mt}$. Phase 3 feed cost totaled $\$ 135.18$ and $\$ 157.12$, respectively, for the SF and LF heifers. The combined cost for the three increasing gain phases totaled $\$ 263.34 /$ heifer for the SF group and \$315.89/heifer for the LF group. Market prices used in the analysis were obtained from the United States Department of Agriculture-Agricultural Marketing Service (USDA-AMS) website. Beginning heifer values in October 2010 were computed by multiplying the average heifer weight of each group by the North Dakota weekly average auction market price for each group (USDA-AMS, 2010). Non-pregnant ending heifer values were computed in the same manner using the North Dakota weekly average auction market price for September 2011 (USDA-AMS, 2011). The net cost/pregnant heifer was calculated using the formula developed by Feuz (1992) and also used by Larson et al. (2011). The total value of all nonpregnant heifers was subtracted from the total costs of all heifers in each development group. That adjusted development cost value was divided by the number of pregnant heifers in each group to determine the cost of developing each pregnant heifer.

\section{Statistical analysis}

The data was analyzed using the generalized least squares mixed analysis procedure of SAS (SAS, 2002). The main effect included heifer frame score treatment (fixed) and pen group (random) served as the experimental unit for the study. Least square means were used to partition treatment effects and differences were considered significant at $\mathrm{p} \leq 0.05$.

\section{RESULTS}

The pre-trial management growth and cost for the two heifer frame score groups, which were managed as a common group for production Phases $\mathrm{P} 1$ and $\mathrm{P} 2$, are shown in Table 2 and were critical steps in preparation for the final P3 growing and breeding trial (Table 3). Phase 1 heifer gains grazing dormant forage corn and corn residue plus supplemental medium-quality mixed hay were restricted during the $209 \mathrm{~d}$ period $(0.26 \mathrm{vs} 0.22 \mathrm{~kg} / \mathrm{d}$ for the $\mathrm{SF}$ and $\mathrm{LF}$, respectively). Compared to restricted gain of P1, P2 grazing of spring and early summer $\mathrm{CWG}$ pasture improved ADG of the SF heifers by $81 \%$ and the LF heifers by $172 \%$. Comparing ADG during P3 with that of P2, the SF and LF heifer gains improved $62 \%$ and $81 \%$, respectively. During the P3 growing-breeding period in drylot (Table 2), ADG between the SF and LF heifers did not differ (0.85 vs 0.97 $\mathrm{kg} / \mathrm{d}$, respectively, $\mathrm{p}=0.09)$. Although there was no

Table 2. Phases 1 and 2 pre-trial management growth performance and production cost

\begin{tabular}{lcc}
\hline & \multicolumn{2}{c}{ Treatments } \\
\cline { 2 - 3 } & SF & LF \\
\hline Number of heifers & 50 & 50 \\
Phase 1. fall-winter dormant grazing & & \\
Days (Oct 13 to May10) & 209 & 209 \\
Start weight (Weaning, kg) & 216 & 267 \\
End weight (kg) & 270 & 312 \\
Gain (kg) & 54 & 45 \\
ADG (kg) & 0.258 & 0.215 \\
Feed cost/heifer (\$) & 110.04 & 137.72 \\
Feed cost day (\$) & 0.53 & 0.66 \\
Phase 2. spring CWG grazing & & \\
Days (May 10 to July 6) & 58 & 58 \\
Start weight (kg) & 270 & 312 \\
End weight (kg) & 297 & 347 \\
Gain (kg) & 27 & 35 \\
ADG (kg) & 0.466 & 0.603 \\
Grazing cost/heifer (\$) & 18.13 & 21.05 \\
\hline SF,
\end{tabular}

SF, small frame heifers; LF, large frame heifers; ADG, average daily gain; CWG, crested wheatgrass. 
Table 3. Phase 3 growing-breeding period growth, efficiency and cost per day

\begin{tabular}{|c|c|c|c|c|}
\hline & \multicolumn{2}{|c|}{ Treatments } & \multirow{2}{*}{ SEM } & \multirow{2}{*}{ p-value* } \\
\hline & SF & LF & & \\
\hline Number of heifers & 50 & 50 & & \\
\hline Heifer frame score & 3.50 & 5.56 & 0.33 & 0.001 \\
\hline \multicolumn{5}{|l|}{ Growing-breeding growth } \\
\hline Drylot Days (July 6 to Sept.29) & 85 & 85 & & \\
\hline Start weight $(\mathrm{kg})$ & 297 & 347 & 22.46 & 0.001 \\
\hline Start breeding weight (Aug 11, kg) & 320 & 382 & 24.33 & 0.001 \\
\hline End weight $(\mathrm{kg})$ & 369 & 429 & 28.68 & 0.001 \\
\hline Gain $(\mathrm{kg})$ & 72 & 82 & 8.63 & 0.09 \\
\hline $\mathrm{ADG}(\mathrm{kg})$ & 0.85 & 0.97 & 0.10 & 0.09 \\
\hline \multicolumn{5}{|l|}{ Growing-breeding feed efficiency (DM) } \\
\hline Feed head/d (kg) & 9.44 & 11.34 & 0.74 & 0.001 \\
\hline Feed:gain $(\mathrm{kg})$ & 11.14 & 11.75 & 0.48 & 0.41 \\
\hline Feed cost/heifer $(\$)$ & 135.18 & 157.12 & 5.00 & 0.03 \\
\hline Feed cost $/ \mathrm{d}(\$)$ & 1.5906 & 1.913 & 0.056 & 0.001 \\
\hline Feed cost/kg of gain $(\$)$ & 0.87 & 0.91 & 0.037 & 0.41 \\
\hline \multicolumn{5}{|l|}{ Combined grazing and feedlot cost } \\
\hline Total cost/heifer $(\$)$ & 263.34 & 315.89 & & \\
\hline Cost heifer/d (352 days) (\$) & 0.75 & 0.90 & & \\
\hline
\end{tabular}

SF, small frame heifers; LF, large frame heifers; SEM, pooled standard error of the mean; ADG, average daily gain.

* Means are considered different at $(\mathrm{p} \leq 0.05)$.

difference in ADG between the SF and LF heifers, DMI for the SF heifers was $20.1 \%$ less than the LF heifers (9.44 vs $11.34 \mathrm{~kg} / \mathrm{hd} / \mathrm{d}$, respectively; $\mathrm{p}=0.001)$. The relationship between ADG and DMI, for the two heifer treatment groups, resulted in a feed to gain ratio between the SF and LF

Table 4. Effect of frame score on economically important ultrasound live animal measurements

\begin{tabular}{lcccc}
\hline & \multicolumn{2}{c}{ Treatments } & \multirow{2}{*}{ SEM } & \multirow{2}{*}{ p-value* } \\
\cline { 2 - 3 } & SF & LF & & \\
\hline LMA $\left(\mathrm{cm}^{2}\right)$ & & & & \\
$\quad$ May & 35.12 & 37.89 & 0.895 & 0.002 \\
October & 46.42 & 50.62 & 1.01 & 0.04 \\
$\quad$ Change & 11.30 & 12.73 & 0.735 & 0.19 \\
LMA /45.4 kg BW $\left(\mathrm{cm}^{2}\right)^{1}$ & & & & \\
$\quad$ May & 2.20 & 1.78 & 0.113 & 0.02 \\
October & 1.56 & 1.26 & 0.081 & 0.003 \\
$\quad$ Change & -0.64 & -0.52 & 0.044 & 0.10 \\
12 & & & & \\
$\quad$ rib fat thickness $(\mathrm{mm})$ & & & & \\
May & 0.218 & 0.236 & 0.029 & 0.67 \\
$\quad$ Change & 0.467 & 0.457 & 0.023 & 0.63 \\
IMF $(\%)$ & 0.249 & 0.221 & 0.035 & 0.48 \\
$\quad$ May & & & & \\
$\quad$ October & 2.23 & 2.20 & 0.007 & 0.07 \\
Change & 3.22 & 3.13 & 0.129 & 0.59 \\
\hline
\end{tabular}

SF, small frame heifers; LF, large frame heifers; SEM, pooled standard error of the mean; LMA, Longissimus dorsi muscle area; IMF, intramuscular fat.

${ }^{1}$ Ratio contrasting LMA/45.4 kg of BW.

* Means are considered different at $(\mathrm{p} \leq 0.05)$. heifers that did not differ (11.14 vs $11.75 \mathrm{~kg} / \mathrm{kg}$ gain, respectively; $p=0.41$ ).

Economically important live animal measurements were obtained using real-time ultrasound for LMA, ratio of LMA/unit of BW $\left(\mathrm{cm}^{2}\right)$, 12th rib fat thickness, and percent IMF (Table 4). The LMA for the LF heifers was larger in May $(p=0.002)$ and October $(p=0.04)$. However, when the ratio of LMA/unit of BW $\left(\mathrm{cm}^{2}\right)(45.4 \mathrm{~kg})$ was compared in May and October, SF LMA was greater than LF heifers in May $(p=0.02)$ and in October $(p=0.003)$. Rib fat thickness (e.g., between the 12th and 13th ribs) did not differ between SF and LF heifers either in May ( $p=0.67$ ) or October $(p=0.63)$. There was a tendency for SF heifers to have greater percent IMF in May $(p=0.07)$, but there was no difference in October $(\mathrm{p}=0.59)$. During the grazing and drylot period from May to October, the percent IMF deposition increased $44.4 \%$ and $42.3 \%$, respectively, for the SF and LF heifers, providing supportive evidence that the heifers were on a positive plane of nutrition leading up to and during the breeding season.

The effect of the heifer development procedure on puberty, percent of mature BW at the start of the breeding season, breeding cycle pregnancy rate, and overall reproductive performance are shown in Table 5. At the start of P2 on May 10, the heifer percent of mature BW was $48.7 \%$ and $46.8 \%$ respectively, for the SF and LF heifers, and compared to the SF heifers, a greater number of LF heifers had reached puberty $(18.0 \%$ vs $40.0 \%$, respectively; $\mathrm{p}=0.02)$. Then, during the $93 \mathrm{~d}$ period from May 10 to the start of the breeding season on August 11 (e.g., P2 and the 
Table 5. Effect of frame score on puberty, percent of mature BW, and reproductive performance

\begin{tabular}{|c|c|c|c|c|}
\hline & \multicolumn{2}{|c|}{ Treatments } & \multirow{2}{*}{ SEM } & \multirow{2}{*}{ p-value* } \\
\hline & SF & LF & & \\
\hline Start breeding heifer age (days) $^{1}$ & 505 & 499 & 2.93 & 0.14 \\
\hline May heifer weight $(\mathrm{kg})$ & 270 & 312 & 21.02 & 0.003 \\
\hline May percent cycling $(\%)^{1}$ & 18.0 & 40.0 & 7.55 & 0.02 \\
\hline May percent of mature cow BW $(\%)^{2}$ & 48.7 & 46.8 & & \\
\hline August start breeding weight ( kg) & 320 & 382 & 24.33 & 0.0002 \\
\hline Start breeding percent cycling $(\%)^{1}$ & 90.0 & 96.0 & 2.83 & 0.07 \\
\hline Start breeding percent of estimated mature cow BW $(\%)^{2}$ & 57.8 & 57.3 & & \\
\hline \multicolumn{5}{|l|}{ Breeding cycle pregnancy $(\%)$} \\
\hline First cycle $(21 \mathrm{~d})$ & 62.0 & 70.0 & 9.33 & 0.53 \\
\hline Second cycle (42 d) & 16.0 & 10.0 & 4.80 & 0.40 \\
\hline Third cycle $(63 \mathrm{~d})$ & 8.0 & 4.0 & 3.87 & 0.49 \\
\hline Total & 86.0 & 84.0 & 5.57 & 0.62 \\
\hline Non-pregnant & 14.0 & 16.0 & 5.57 & 0.62 \\
\hline
\end{tabular}

BW, body weight; SF, small frame heifers; LF, large frame heifers; SEM, pooled standard error of the mean.

${ }^{1}$ Serum progesterone assay recovered $10 \mathrm{~d}$ apart. See text for assay details.

${ }^{2}$ Estimated mature cow BW from DREC cow database: SF, $554 \mathrm{~kg} ; \mathrm{LF}, 667 \mathrm{~kg}$.

* Means are considered different at $(\mathrm{p} \leq 0.05)$.

first $36 \mathrm{~d}$ of P3), the number of SF heifers that had attained puberty increased 5-fold, whereas the increase was 2.4 times for the LF heifers. However, there was no difference in the percent of SF and LF heifers that were pubertal at the start of the breeding season $(90.0 \%$ vs $96.0 \%$, respectively, $\mathrm{p}=0.07$ ). This is presumed to be influenced by frame score and not age. Using the DREC cow herd database, the percent of mature BW attained by the start of the breeding season was $57.8 \%$ and $57.3 \%$ for the SF and LF heifers, respectively, and did not differ between groups (CHAPS, 2000). Using natural service and a $50 \mathrm{~d}$ breeding period, first $21 \mathrm{~d}(\mathrm{p}=0.53)$, second $42 \mathrm{~d}(\mathrm{p}=0.40)$, and third $63 \mathrm{~d}$ ( $p=0.49$ ) breeding cycle pregnancy rates did not differ between SF and LF heifers. Furthermore, overall pregnancy rate for SF and LF heifers was $86.0 \%$ and $84.0 \%$, respectively and did not differ between groups $(\mathrm{p}=0.62)$.

Based on economic assumptions for feed cost calculated during P1 and P2 between SF and LF heifers, feed cost for SF heifers was lower for the entire $352 \mathrm{~d}$ development

Table 6. Heifer frame score development cost

\begin{tabular}{|c|c|c|c|c|}
\hline & \multicolumn{2}{|c|}{ Treatments } & \multirow{2}{*}{ SEM } & \multirow{2}{*}{ p-value* } \\
\hline & SF & LF & & \\
\hline $\begin{array}{l}\text { Heifer value } \\
\text { At weaning (\$) }\end{array}$ & 525 & 626 & 24.51 & 0.005 \\
\hline $\begin{array}{l}\text { Total development } \\
\text { Cost/heifer }(\$)\end{array}$ & 789 & 939 & 24.51 & 0.001 \\
\hline End heifer value (\$) & 1,025 & 1,131 & 35.36 & 0.005 \\
\hline Net cost/pregnant heifer $(\$)^{1}$ & 745 & 899 & 32.30 & 0.004 \\
\hline $\begin{array}{l}\text { SF, small frame heifers; LF, lar } \\
\text { error of the mean. } \\
{ }^{1} \text { Net cost per pregnant heifer wa } \\
\text { of Feuz (1992). }\end{array}$ & frame he & $\begin{array}{l}\text { fers; SE } \\
\text { accord }\end{array}$ & $\begin{array}{l}\text { M, poole } \\
\text { g to the }\end{array}$ & $\begin{array}{l}\text { d standard } \\
\text { procedure }\end{array}$ \\
\hline
\end{tabular}

period, and feed cost per day for the SF heifers was $19.9 \%$ less than the LF heifers. Economic analysis comparing SF and LF heifers (Table 6) was conducted according to the procedure of Feuz (1992), which accounted for the sale of non-pregnant heifers, and determined the net cost per pregnant heifer to be $\$ 745$ for the SF heifers and $\$ 899$ for the LF heifers $(\mathrm{p}=0.004)$; a difference of $\$ 154$.

\section{DISCUSSION}

For a large number of heifers to conceive and maintain pregnancy in the first $21 \mathrm{~d}$ of the breeding cycle, it is desirable that a high percentage of heifers have attained puberty by the start of the breeding season, and nutritional regimens that result in a high percentage of heifers becoming pregnant early in the breeding season have a greater potential to increase lifetime profitability (Patterson et al., 2003). Growing heifers to $60 \%$ to $65 \%$ of mature BW so that they have experienced more than one estrous cycle before the start of the breeding season has been the recommended goal by animal scientists for many years (Short and Bellows, 1971; Byerley et al., 1987; Patterson et al., 1992; Patterson et al., 2005). The increasing gain development method reported in this research investigation relies upon a divergent approach to attain high reproductive success using an increasing gain method and a $50 \mathrm{~d}$ breeding season. The data reported herein agrees with results reported by Funston and Deutscher (2004), Martin et al. (2008), and Freetly et al. (2011), indicating that heifers attaining $50 \%$ to $57 \%$ of mature BW by the start of the breeding season can have similar pregnancy rates as heifers grown to $60 \%$ to $65 \%$ of mature $\mathrm{BW}$, and is an appropriate extensive, lower-input, less-intense, protocol for 
transitioning heifers from a March-April calving period to May-June calving period. This protocol is especially valuable, because North American cattlemen are faced with less available experienced labor for calving during the harsh March-April calving period; therefore, cow-calf producers are moving to May-June calving, which is more in synch with when wildlife in the northern Great Plains give birth to their young.

Using the concept of developing replacement heifers to a percent of mature $\mathrm{BW}$, this research focused on comparing the growth, reproductive performance, and development procedure cost for heifers representing two

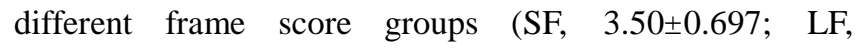
$5.56 \pm 0.569$ ) that were developed using a less intense increasing gain regimen. The increasing gain regimen included the integration of grazing (P1 and P2) and a drylot growing-breeding period (P3).

Modest gains ranging from 0.22 to $0.26 \mathrm{~kg} / \mathrm{d}$ were documented during the P1 winter dormant grazing period. This level of gain would be considered too slow for heifers destined to be bred for March-April calving. However, for cow-calf producers that desire to change their calving season to a May-June calving period, the modest level of winter gain was not considered to be a problem, since there was ample time for the heifers to attain the pre-breeding target BW of $57 \%$ by the start of the breeding season on August 11, 2011.

At the time the heifers were moved to CWG on May 10, 2011, heifers in both frame score treatment groups were not ready for breeding due to the low percentage of pubertal heifers $(18.0 \%$ and $40.0 \%$ for the SF and LF heifers, respectively). Our research group does not have a specific explanation for the observed difference; nonetheless, the significantly lower number of pubertal SF heifers at the end of the wintering period was a stark demarcation from what was anticipated. We anticipated that there would have been a greater number of SF heifers that were pubertal than LF heifers. Our explanation for the observed difference is that the SF heifer growth rate needed to be greater in order for the SF heifer to fully express its genetic potential for earlier pubertal status. We hypothesize that energy restriction during the wintering phase is the most probable cause for the depressed pubertal status based on the SF heifer pubertal change during the $93 \mathrm{~d}$ period that preceded the start of the breeding season in drylot. During the subsequent 93 d period between May 10, 2011 and August 11, 2011 grazing CWG and the first 5 weeks in drylot consuming a nutrient dense alfalfa-co-product TMR diet, pubertal status improved remarkably among both SF and LF heifers (90.0\% and $96.0 \%$, respectively; $\mathrm{p}=0.07)$. The high percentage of pubertal heifers at the start of the breeding season supported a high total pregnancy rate among both frame score groups $(\mathrm{p}=0.62)$. August breeding for MayJune calving provided more time for heifers in the study to reach the desired target weight and sexual maturity without relying on high energy grain supplementation. Similar heifer reproductive success has been reported by others (Lynch et al., 1996; Grings et al., 1999; Poland et al., 2001); however, the methods employed were grain-based for gain patterns ranging from level gain to a variety of gain switching regimens prior to the start of the breeding season. By contrast, the reproductive success reported here was predominately a combination of forage and highly digestible fiber-based ingredients, but due to the slower rate of gain, more time was needed to reach the target goal before the start of breeding.

With respect to heifer growth and maturity, our data agrees more closely with the recent work of Freetly et al. (2011) who summarized US Department of Agriculture Agricultural Research Service, Meat Animal Research Center data to evaluate Angus, Hereford, and MARC-III female growth curves to determine mature size and maturity rates among Bos indicus and Bos tarurus cattle, and concluded that for developing heifers attainment of an absolute BW, or age, was less critical than developing heifers across breeds to a proportion of mature BW.

Although our study did not include a full season drylot treatment, Funston and Larson (2011), conducted a 3-yr heifer development study among heifers calving at the same time of year and compared a drylot treatment to an extensive corn residue grazing treatment, and reported that heifers developed either in the drylot or grazing corn residue for an average $111 \mathrm{~d}$ had similar $21 \mathrm{~d}$ calf birth date, calf birth weight, and dystocia score. Cow longevity after the second breeding season did not differ between the two development systems, but the extensive winter grazing protocol reduced development cost by $\$ 45$ per pregnant heifer. Interestingly, transitioning heifers to a two month later calving period, using a slower-gain increasing-energy protocol, reduced direct costs in the current study and after the opportunity cost for non-pregnant heifers was accounted for, the net cost per pregnant SF heifer was $\$ 154.00$, or $20.7 \%$ less than the LF heifer. Our data and the results reported by others show that low intensity and direct marketing of non-pregnant heifers can collectively reduce heifer development cost.

The non-confinement phases of the study were the least expensive and the final P3 drylot growing-breeding period was the most expensive. By design, the drylot phase cost was higher, because the plane of nutrition was kept high to maintain adequate growth and to support embryonic survival. Embryonic survival, whether post artificial insemination or natural breeding, can be impaired when the plane of nutrition declines immediately following breeding 
when heifers are moved from a high drylot plane of nutrition to a lower plane of nutrition (Perry et al., 2013). Evidence that embryonic survival can be impaired when the plane of nutrition declines has been reported by Perry et al. (2009), Arias et al. (2012), and Kruse et al. (2013).

\section{IMPLICATION}

Results of this heifer development study imply that March-April born SF and LF heifers of similar age can be successfully developed to $57 \%$ of mature BW by the start of the breeding season for May-June calving using a lower cost combination of non-confinement and confinement to manage an increasing gain energy regimen from weaning to breeding. The data also suggests that, when cow-calf producers use a combination of extensive management and confinement, a high pregnancy rate for both SF and LF heifers is attainable, and the development cost for SF heifers will be less.

\section{ACKNOWLEDGMENTS}

Research reported here was supported by the North Dakota State Univ. Agric. Exp. Sta. Project number 6259 and partial funding was provided by a USDA/NIFA Sustainable Agriculture Research and Education Grant \#NCR LNC11-335.

\section{REFERENCES}

Arias, R. P., P. J. Gunn, R. P. Lemanager, and S. L. Lake. 2012. Effects of post-AI nutrition on growth performance and fertility of yearling beef heifers. Proceedings, Western Section, American Society of Animal Science. 63:117-121.

AOAC. 2010. Official Methods of Analysis of Official Analytical Chemists, 18th ed. Arlington, VA, USA.

Beef Improvement Federation (BIF). 2010. Guidelines for Uniform Beef Improvement Programs, 9th ed., pp 30. Online Available from: http://www.beefimprovement.org/PDFs/ guidelines/Guidelines-9th-Edition.pdf. Accessed November 14, 2012.

Byerley, D. J., R. B. Staigmiller, J. G. Berardinelli, and R. E. Short. 1987. Pregnancy rates of beef heifers bred either on pubertal or third estrus. J. Anim. Sci. 65:645-650.

CHAPS. 2000. Cow Herd Appraisal Performance Software. http://www.chaps2000.com/. Accessed December 15, 2012.

Dhuyvetter, K. C., G. T. Tonsor, and S. Johnson. 2012. Raising beef replacement heifers. In: Kansas State University Farm Management Guide Bulletin MF2566. http://www.ksre.ksu. edu/bookstore/pubs/mf2566.pdf. Accessed June 10, 2013.

Endecott, R. L., R. N. Funston, J. T. Mulliniks, and A. J. Roberts. 2013. Joint Alpharma-Beef Species Symposium: Implications of beef heifer development systems and lifetime productivity. J. Anim. Sci. 91:1329-1335.

Engel, C. L., H. H. Patterson, and G. A. Perry. 2008. Effect of dried corn distillers grains plus solubles compared with soybean hulls, in late gestation heifer diets, on animal and reproductive performance. J. Anim. Sci. 86:1697-1708.

Feuz, D. M. 1992. Replacement beef heifer economics: When prices and reproductive performance are uncertain. American Society of Farm Managers and Rural Appraisers 56:61-66.

Fox, D. G., C. J. Sniffen, and J. D. O. Connor. 1988. Adjusting nutrient requirements of beef cattle for animal and environmental variations. J. Anim. Sci. 66:1475-1495.

Freetly, H. C., L. A. Kuehn, and L. V. Cundiff. 2011. Growth curves of crossbred cows sired by Hereford, Angus, Belgian Blue, Brahman, Boran, and Tuli bulls, and the fraction of mature body weight and height at puberty. J. Anim. Sci. 89: 2373-2379.

Funston, R. N. and G. H. Deutscher. 2004. Comparison of target breeding weight and breeding date for replacement beef heifers and effects on subsequent reproduction and calf performance. J. Anim. Sci. 82:3094-3099.

Funston, R. N. and D. M. Larson. 2011. Heifer development systems: Dry-lot feeding compared with grazing dormant winter forage. J. Anim. Sci. 89:1595-1602.

Grings, E. E., R. B. Staigmiller, R. E. Short, R. A. Bellows, and M. D. MacNeil. 1999. Effects of stair-step nutrition and trace mineral supplementation on attainment of puberty in beef heifers of three sire breeds. J. Anim. Sci. 77:810-815.

Goering, H. K. and P. J. Van Soest. 1970. Forage fiber analyses. Agriculture Handbook No: 379, ARS-USDA, Washington, DC, USA.

Kruse, S. G., B. J. Funnell, S. L. Bird, H. P. Dias, S. L. Lake, R. P. Arias, G. A. Perry, O. L. Swanson, E. L. Larimore, and G. A. Bridges. 2013. Influence of post-insemination nutrition on embryonic development in beef heifers. J. Anim. Sci. 91 (ESuppl. 2):Abst.589:635. http://www.jtmtg.org/jam/2013/ abstracts.asp. Accessed September 5, 2014.

Larson, D. M., A. S. Cupp, and R. N. Funston. 2011. Heifer development systems: A comparison of grazing winter range or corn residue. J. Anim. Sci. 89:2365-2372.

Lesmeister, J. L., P. J. Burfening, and R. L. Blackwell. 1973. Date of first calving in beef cows and subsequent calf production. J. Anim. Sci. 36:1-6.

Lynch, J. M., G. C. Lamb, B. L. Miller, J. E. Minton, R. C. Cochran, and R. T. Brandt. 1996. Timing of gain does not alter puberty and reproductive performance of beef heifers fed a high roughage diet. Proceedings of Cattlemen's Day, 1996. March 1, 1996; Kansas State University, Manhattan, KS, USA. http://krex.k-state.edu/dspace/handle/2097/4844 Accessed September 5, 2014.

Martin, J. L., K. W. Creighton, J. A. Musgrave, T. J. Klopfenstein, R. T. Clark, D. C. Adams, and R. N Funston. 2008. Effect of prebreeding body weight or progestin exposure before breeding on beef heifer performance through the second breeding season. J. Anim. Sci. 86:451-459.

North Dakota Farm and Ranch Business Management Education Annual Report. 2010. Beef Replacement Heifers-Average Per Head All Farms. 2010:81.

North Dakota Farm and Ranch Business Management Education Annual Report, 2011. Beef Replacement Heifers-Average Per Head All Farms. 2011:78. 
North Dakota Farm and Ranch Business Management Education Annual Report, 2012. Beef Replacement Heifers-Average Per Head All Farms. 2012:78.

Patterson, D. J., R. C. Perry, G. H. Kiracofe, R. A. Bellows, R. B. Staigmiller, and L. R. Corah. 1992. Management considerations in heifer development and puberty. J. Anim. Sci. 70:4018-4035.

Patterson, H. H., D. C. Adams, T. J. Klopfenstein, R. T. Clark, and B. Teichert. 2003. Supplementation to meet metabolizable protein requirements of primiparous beef heifers: II. Pregnancy and economics. J. Anim. Sci. 81:563-570.

Patterson, H. H., T. R. Clark, R. Salverson, W. Fahsholtz, and T. Line. 2005. Heifer development: Revisiting target weights and management approaches. Proceedings, the Range Beef Cow Symposium XIX. December 6 to 8, 2005; University of South Dakota, Vermillion, SD, USA.

Perry, G. A, J. Walker, C. Wright, and K. Olson. 2009. Impact of method of heifer development and post-AI management on reproductive efficiency. Proceedings, Range Beef Cow Symposium XXI. December 1-3, 2009; Casper, WY, USA.

Perry, G. A., B. L. Perry, J. A. Walker, C. L. Wright, R. R. Salverson, and H. H. Patterson. 2013. Evaluation of prior grazing experience on reproductive performance in beef heifers. Prof. Anim. Sci. 29:595-600.

Perry, R. C., L. R. Corah, R. C. Cochran, J. R. Brethour, K. C. Olson, and J. J. Higgins. 1991. Effects of hay quality, breed, and ovarian development on onset of puberty and reproductive performance of beef heifers. J. Prod. Agric. 4:13-18.
Poland, W. W. and K. A. Ringwall. 2001. Effect of nutritional management for either constant or stair-stepped rates of gain on subsequent breeding performance of beef heifer calves. Proc. West. Sec. Am. Soc. An. Sci. 52:582-586.

Roberts, A. J., T. W. Geary, E. E. Grings, R. C. Waterman, and M. D. MacNeil. 2009. Reproductive performance of heifers offered ad libitum or restricted access to feed for a one hundred forty-day period after weaning. J. Anim. Sci. 87:30433052 .

SAS. 2002. Institute SAS Language and Procedure. Inc. Cary, NC, USA.

Short, R. E. and R. A. Bellows. 1971. Relationships among weight gains, age at puberty and reproductive performance in heifers. J. Anim. Sci. 32:127-131.

Tilley, J. M. A. and R. A. Terry. 1963. A two-stage technique for the in vitro digestion of forage crops. Grass Forage Sci. 18:104-111.

USDA (Agricultural Marketing Service). 2010. North Dakota Weekly Auction Summary. http://search.ams.usda.gov/mndms/ 2010/10/SF_LS79620101015.TXT. Accessed October 15, 2011.

USDA (Agricultural Marketing Service). 2011. North Dakota Weekly Auction Summary. http://search.ams.usda.gov/mndms/ 2011/09/SF_LS79620110930.TXT. Accessed September 30, 2011.

USDA (National Agricultural Statistics Service North Dakota Field Office). 2011. Non-irrigated pasture and hay land, average rental rates and values, North Dakota. 2011. Ag Statistics No. 80: 92. 